PF 2019 (LXXIV): 277-279

HANNA POPOWSKA-TABORSKA prof. em.

Instytut Slawistyki Polskiej Akademii Nauk

ul. Bartoszewicza 1b m. 17

00-337 Warszawa

tel. +48228267688

e-mail: hanna.taborska@gmail.com

\title{
O POCHODZENIU NAZWY NIEBORÓW
}

SŁOWA KLUCZOWE: onomastyka, polskie nazwy miejscowe, etymologia.

KEYWORDS: onomastics, Polish place names, etymology.

\section{ABOUT THE ORIGIN OF THE NIEBORÓW NAME}

\begin{abstract}
The base of the name Nieborów, a village near Łowicz, lies in the Slavic personal name ${ }^{\star}$ Niebor-, consisting of the negation non- and the Proto-Slavic stem ${ }^{\star}$ bor( ${ }^{\star}$ boriti 'defend, fight, prohibit'). Such personal names with negatives are no longer present in Iranian, Germanic, and Balto-Slavic anthroponymy and are probably a remnant of the Indo-European anthroponomical system. There are many ${ }^{\star}$ Niebor- occurences in Polish local names and in old Polish personal names. It referred to the so-called magical names aiming at protecting their owner or confusing the enemy, but equally well, the term could have been a name for a clumsy man unable to fight.
\end{abstract}

„Dlaczego właśnie Nie-borów?” zapytuje zapewne niejeden z przybywających do tej położonej nieopodal Łowicza miejscowości. Na brak lasów narzekać tu przecież nie można, a w przeszłości tych borów było wokół jeszcze znacznie więcej, co z każdej starej mapy można z łatwością wyczytać. I nie będzie ten pytający zdawał sobie sprawy, że ma do czynienia z nazwą wielce szacowną, która z otaczającymi do dziś Nieborów borami nie ma i nie miała oczywiście nigdy nic wspólnego. Nie będzie wiedział, że u podstaw tego nazwania leży najpewniej archaiczna słowiańska nazwa osobowa ${ }^{\star}$ Niebor (Niebór), należąca do tak zwanych imion złożonych, składająca się $\mathrm{w}$ tym wypadku $\mathrm{z}$ negacji ${ }^{*}$ nie- $\mathrm{i}$ z podstawowego rdzenia *bor- często występującego w dawnych imionach słowiańskich 
(por. staropolskie Raci-bor, Woj-bor, Borzy-woj, Sławo-bor, Borzy-sław, Żeli-bor, staroczeskie Chotěbor, staroruskie Pamu-бopz, Вoŭ-бopz), rdzen * bor-zaś łączyć wypada $\mathrm{z}$ uwidocznionym $\mathrm{w}$ wielu językach słowiańskim znaczeniem 'bronić, walczyć, nie dopuszczać, zakazywać'.

Takie złożone nazwy osobowe z zaprzeczeniem nie- w pierwszym członie stanowią dziedzictwo epok bardzo odległych, występują już w antroponimii indoirańskiej, germańskiej i bałtosłowiańskiej i są najpewniej spadkiem po praindoeuropejskim systemie antroponimicznym. Od strony znaczeniowo-stylistycznej zaliczane bywają przez niektórych badaczy do tzw. imion magicznych mających na celu ochronę ich właściciela przed złymi potęgami, odstraszanie wroga bądź zmylenie przeciwnika. Możliwe więc, że ów interesujący nas tu Niebora imieniem swym miał zapewniać swych wrogów, że do walki się nie nadaje (aby tym łatwiej później zaskoczyć ich i pokonać), choć równie dobrze określenie to mogło stanowić po prostu nazwę człowieka nieporadnego, niezdolnego do walki, czyli po prostu nieboraka.

Imię to $\mathrm{w}$ swoim czasie musiało być dość popularne na ziemiach polskich, skoro mamy odnotowaną w źródłach śląską nazwę miejscową Nieborowice, pow. gliwicki, też imię Neborowicz 1407, zaś imię Nieborza, np. Neborza 1388, 1411 (które rekonstruować należy jako ${ }^{*} \mathrm{Ne}-b o r-j a$ ) znane jest $\mathrm{z}$ zapisek sądowych wielkopolskich XIV i XV wieku.

W Słowniku staropolskich nazw osobowych, odnajdujemy też dwa XV-wieczne poświadczenia z Pomorza:

Niebor: Nebor, civis in Dirsow et Clara, uxor eius 1402; Henricus Nebor cum uxore sua Gertrude 1402, ponadto zaś Nebora // Nieborza: Nebora, castelanus in Oberiz 1238; Wladislaus dux...contuli ecclesie sancta Marie in Wratislavia... villam nomine Muclino, his assidentibus... Domoratho, Nebora Petrco XVI in. (1211) (SSNO IV, z. 1: 33). Nasz „łowicki” Nieborów ma również dawne poświadczenia w SG VII 40, 41: de Nyeborow 1476. Dziś zresztą również napotykamy często nazwiska typu Nieborowski, Nieborski, Nieborza, Niebora.

Ps. Nie uchodzi zapewne dedykować tak prostego i krótkiego tekstu Szanownemu Jubilatowi - Wytrawnemu Językoznawcy. Ale należymy przecież do tego samego odchodzącego już pokolenia badaczy, którym takie właśnie niewielkie odkrycia, oparte na skrupulatnie zebranym materiale i w prosty sposób opowiedziane, zwykły sprawiać radość i satysfakcję. Powtórzmy to zatem jeszcze raz! 


\section{Bibliografia}

SG - Słownik geograficzny Królestwa Polskiego i innych krajów słowiańskich, t. I-XV, Warszawa 1880-1902.

SSNO - Słownik staropolskich nazw osobowych, red. i wstęp Witold Taszycki, t. I-VII, Wrocław 1965-1987.

\section{Streszczenie}

Artykuł stanowi etymologiczną analizę nazwy miejscowej Nieborów, ukazując znaczną archaiczność samej formacji na tle antroponimii indoeuropejskiej. 